\title{
Tiotropium: a new therapeutic option in asthma
}

\author{
F. Novelli, F. Costa, M. Latorre, L. Malagrinò, A. Celi, B. Vagaggini P. Paggiaro
}

ABSTRACT: Tiotropium: a new therapeutic option in asthma. F. Novelli, F. Costa, M. Latorre, L. Malagrinò, A. Celi, B. Vagaggini, P. Paggiaro.

Although bronchial hyperresponsiveness to cholinergic agents is a main feature of asthma, the role of anticholinergic drugs in chronic asthma management has been largely underestimated. Several single-dose studies comparing acute bronchodilation induced by ipratropium bromide with salbutamol have shown that salbutamol is more effective than ipratropium in treating asthma.

Recently, tiotropium has been studied in asthma, when added to low-medium dose inhaled corticosteroids (ICS) in unselected moderate asthmatics or in patients with uncontrolled asthma, or with COPD and history of asthma. Later, studies on patients with Arg/Arg beta2-receptor polymorphism demonstrated a similar efficacy of tiotropium in comparison with salmeterol, when both were added to ICS.
More recently, pivotal long-term studies have been performed on severe asthmatics uncontrolled under ICS/LABA combination, showing the efficacy of tiotropium in improving lung function and in increasing the time until the first severe asthma exacerbation. These data support the use of tiotropium on top of ICS/LABA combination in moderate-severe asthmatic patients.

New studies are going to be published on the use of tiotropium in mild and moderate asthmatics, when added to low or medium dose ICS, in comparison with ICS alone or with ICS/LABA combination. These data might extend the indication for using tiotropium in asthma.

Therefore, tiotropium represents now a valid therapeutic option, in addition to the current therapy available for severe asthmatics, and in alternative to LABA in selected asthma populations. The specific asthma phenotype which may be appropriate for tiotropium treatment should still be defined.

Monaldi Arch Chest Dis 2013; 79: 3-4, 109-115.

Keywords: Asthma, Bronchodilator, Tiotropium, Therapy.

Department of Surgery, Medicine, Molecular Biology and Critical Care, University of Pisa, Italy.

Correspondence: Federica Novelli, M.D., Respiratory Pathophysiology Unit, Cardio-Thoracic and Vascular Department, University Hospital of Cisanello, Via Paradisa 2, 56124 Pisa, Italy; e-mail:f.c.78@libero.it

\section{Introduction}

Asthma is a chronic airway inflammatory disease associated with widespread but variable airway obstruction and an exaggerated bronchoconstrictive response to indirect (e.g. cold air, allergens, dust, exercise) or direct (e.g. inhaled methacoline) stimuli. This hyperreactivity is associated with abnormal autonomic nervous system control [1], which may explain the occurrence of symptoms for different triggers. For this reason, the potential usefulness of anticholinergic drugs in the treatment of asthma has been considered in the last 40 years, but up to now, no studies have clearly demonstrated the potential contribution of this treatment in asthma management.

In the last few years some data have been produced on the efficacy of tiotropium in special groups of asthmatic patients (asthma with persistent bronchoconstriction, asthma with polymorphism of beta2-receptor, severe uncontrolled asthma) [2-7], with positive results. More recently, the first large randomized controlled clinical trial on the use of tiotropium as add-on therapy in patients with severe asthma has been published [8], leading to the submission for the use of tiotropium in asthma.
In this short review, we wish to summarize the background of the potential usefulness of anticholinergic drugs in the treatment of asthma, and the results of the more recent data supporting the use of tiotropium.

\section{Airway cholinergic system in asthma}

It is already well known that the parasympathetic system is implicated in the pathogenesis of asthma. At the level of the peribronchial ganglia, the pre-ganglionic parasympathetic fibers of the vagus nerve form cholinergic synapses with postganglionic neurons, which generate postganglionic fibers that innervate the airways. The parasympathetic activity is mediated by muscarinic receptors, in particular the M1 receptors, located on the parasympathetic ganglia, which are responsible for cholinergic transmission, while the M2 receptors, located near the postganglionic endings, have a negative presynaptic feedback in reducing a further release of acetylcholine. M3 receptors, located at the airway smooth muscle and submucosal glands, provide the control of both smooth muscle tone (and thus airway caliber) and mucus secretion. 
Cholinergic tone is thought to be increased in asthma sufferers by several mechanisms: abnormal muscarinic receptor expression, increased acetylcholine from postganglionic fiber endings, decreased levels of neuromodulators that attenuate cholinergic neurotransmission. This abnormal cholinergic hyper-sensitivity of an asthmatic's airways is highlighted by the bronchoconstrictive response to doses of inhaled cholinergic agents (acetylcholine and methacholine) that do not affect normal subjects. Moreover, anticholinergic drugs such as atropine have demonstrated some protective effects from bronchoconstriction induced by different non specific stimuli (histamine, cold air, ultrasonically nebulized distilled water) $[9,10]$ and a partial inhibition of immediate airway response to allergen [11]. For all of these reasons, cholinergic antagonists have been tested as potential drugs for the treatment of obstructive airway diseases. Systemic administration of atropine is associated with an unacceptably high rate of adverse events, and inhalation route is ineffective due to the poor water solubility of atropine. The available anticholinergic drugs for respiratory disease are inhaled, and combine a potent local anticholinergic activity with a poor systemic absorption.

\section{Short-acting anticholinergic vs beta2-agonist drugs in asthma}

The first inhaled anticholinergic drug had a short duration of action, so had to be administered multiple times per day, and was a nonselective antagonist of M1, M2 and M3 receptors (the antagonism of M2 allows further release of presynaptic acetylcholine and may antagonize the bronchodilator effect of the M3 antagonism). Ipratropium bromide has been widely studied in the treatment of asthma, both alone in comparison with SABA as well as in addiction to SABA. However, in almost all studies, salbutamol determined a greater bronchodilation than ipratropium bromide in asthmatic subjects, whereas in normal subjects or in patients with COPD, both drugs determined a similar bronchodilation $[12,13]$. Furthermore, the study comparing ipratropium plus SABA to SABA alone did not find any significant difference in lung function and symptoms between two treatments $[14,15]$. Some data suggested a possible benefit of anticholinergics in a certain subsets of patients, such as smokers [16], or in the prevention of the morning dip of peak of expiratory flow (PEF) in nocturnal asthma [17], or in obese patients. In conclusion, the short-acting anticholinergic drugs have not been used in asthma treatment, except for the management of acute severe asthma attacks.

\section{Tiotropium in asthma: preliminary studies}

The second generation of anticholinergic drugs started with tiotropium, the first long-acting anticholinergic drug. Tiotropium differs from the other anticholinergics for the more selective antagonism for M1 and M3 muscarinic receptor subtypes and for a prolonged pharmacologic activity due to the slow dissociation from M1 and M3 receptors. Tiotropium has largely been studied in COPD, demonstrating both its efficacy and safety in this respiratory obstructive disease. However, its role as a treatment for asthma has only recently been studied to systematic clinical investigation. The first trials were conducted on special subgroups of asthmatic patients (patients with asthma and COPD, asthma with persistent bronchoconstriction) but more recently some RCTs have been completed on unselected asthma populations.

Six RCTs and one longitudinal open study included about 2500 patients with asthma, and compared at least 4 weeks tiotropium treatment (range: 4-48 weeks) added to inhaled corticosteroids (ICS) alone or combined with long-acting $\beta 2$-agonists (LABA), with placebo or salmeterol. Apart from the study carried out by Magnussen which took into account patients affected by COPD and asthma [3], the other studies excluded COPD patients and evaluated persistent asthmatics requiring daily therapy. Three studies were conducted on severe asthmatics with persistent bronchoconstriction, symptomatic despite therapy with a high-dose ICS and LABA $[2,4,6]$, while other studies were performed on uncontrolled asthmatics [5, 7]. These studies are summarized in table 1 .

The efficacy of tiotropium has been assessed primarily through impact on lung function evaluated by spirometry or peak expiratory flow (PEF). Moreover, other important outcomes, including exacerbations, symptoms and quality of life, were taken into account.

In a first pilot randomized crossover study of Fardon et al [2], 18 non-smoking patients with severe persistent asthma (mean $\mathrm{FEV}_{1}: 51 \%$ of predicted) were treated with HFA-fluticasone propionate $250 \mathrm{mcg} \mathrm{BD} / \mathrm{salmeterol} 50 \mathrm{mcg} \mathrm{BD}$ plus tiotropium bromide $18 \mathrm{mcg}$ OD, or HFA-fluticasone propionate $250 \mathrm{mcg} \mathrm{BD} / \mathrm{salmeterol} 50 \mathrm{mcg}$ $\mathrm{BD}$ plus placebo, for 4 weeks after a run-in period of 4 weeks with HFA-fluticasone $500 \mathrm{mcg} \mathrm{BD.} \mathrm{Pa-}$ tients performed spirometry and body plethysmography in order to evaluate the effect of halving the fluticasone dose with the addition of salmeterol alone or salmeterol plus tiotropium. Both adding salmeterol alone and salmeterol/tiotropium to half the dose of fluticasone led to an improvement vs baseline in morning PEF $(+41.5 \mathrm{~L} / \mathrm{min}(\mathrm{p}<0.01)$ and $+55.3 \mathrm{~L} / \mathrm{min}(\mathrm{p}<0.01)$ respectively) and Raw; moreover salmeterol/tiotropium also improved $\mathrm{FEV}_{1}(+0.17 \mathrm{~L}, \mathrm{p}<0.05)$ and FVC $(+0.24 \mathrm{~L}, \mathrm{p}<0.05)$. There were no significant changes in symptoms or quality of life compared to baseline in both treatments, which were not significantly different between them.

Following this first study, randomized trials were conducted, both on patients with moderate asthma as well as on those with severe asthma, and also on patients with COPD and a history of asthma.

Peters et al conducted a large randomized, cross-over, placebo-controlled study that compared the addiction of tiotropium bromide to ICS versus doubling dose ICS versus ICS/LABA combination, for 14 weeks, on 210 asthmatics with 
Table 1. - RCTs on the efficacy of tiotropium on lung function and symptoms in asthmatic patients.

\begin{tabular}{|c|c|c|c|c|c|c|}
\hline Study & $\begin{array}{l}\text { Inclusion } \\
\text { criteria }\end{array}$ & $\begin{array}{l}\text { No. of } \\
\text { patients }\end{array}$ & $\begin{array}{l}\text { Asthma } \\
\text { severity }\end{array}$ & $\begin{array}{l}\text { Trial } \\
\text { design }\end{array}$ & $\begin{array}{l}\text { Lung function } \\
\text { outcome }\end{array}$ & $\begin{array}{l}\text { Clinical } \\
\text { outcome }\end{array}$ \\
\hline $\begin{array}{l}\text { Fardon } \\
2007[2]\end{array}$ & $\begin{array}{l}\text { Severe } \\
\text { persistent } \\
\text { asthma, } \\
\text { FEV }_{1} \\
\leq 65 \% \text { pred., } \\
\text { no history } \\
\text { of smoking }\end{array}$ & 26 & $\begin{array}{l}\text { Pre-BD } \\
\text { FEV }_{1} \text { : } \\
51 \% \text { pred. } \\
\text { on full } \\
\text { dose ICS }\end{array}$ & $\begin{array}{l}\text { Randomised, placebo- } \\
\text { controlled, crossover; } \\
4 \text { weeks of half dose } \\
\text { ICS+salmeterol or } \\
\text { half dose ICS+salmeterol } \\
\text { +tiotropium after a run-in } \\
\text { period with ICS alone }\end{array}$ & $\begin{array}{l}\text { Improvement in morning PEF } \\
\text { and RAW in ICS+salmeterol } \\
\text { vs baseline. Improvement } \\
\text { in morning PEF, RAW, FEV } \\
\text { and FVC in ICS+salmeterol+ } \\
\text { tiotropium vs baseline. } \\
\text { No difference between } \\
\text { ICS+salmeterol and ICS+ } \\
\text { salmeterol+tiotropium }\end{array}$ & $\begin{array}{l}\text { No difference in } \\
\text { mini-AQLQ score }\end{array}$ \\
\hline $\begin{array}{l}\text { Magnussen } \\
2008 \text { [3] }\end{array}$ & $\begin{array}{l}\text { COPD } \\
\text { and asthma, } \\
\mathrm{FEV}_{1}<80 \% \\
\text { of pred. }\end{array}$ & 472 & $\begin{array}{l}\text { Pre-BD } \\
\mathrm{FEV}_{1}: \\
53 \% \text { pred. }\end{array}$ & $\begin{array}{l}\text { Randomised, placebo- } \\
\text { controlled; } 12 \text { weeks } \\
\text { of tiotropium or placebo } \\
\text { in addition to basal therapy }\end{array}$ & $\begin{array}{l}\text { Increase in } \mathrm{FEV}_{1} \text { area under } \\
\text { the curve }(\mathrm{AUC}) \text { from } 0 \text { to } 6 \mathrm{~h} \\
\text { and in morning pre-dose } \mathrm{FEV}_{1} \\
\text { in tiotropium vs placebo }\end{array}$ & $\begin{array}{l}\text { Reduction in rescue } \\
\text { medication compared } \\
\text { to baseline in } \\
\text { tiotropium vs placebo }\end{array}$ \\
\hline $\begin{array}{l}\text { Park } \\
2009 \text { [4] }\end{array}$ & $\begin{array}{l}\text { Severe } \\
\text { persistent } \\
\text { asthma, } \\
\text { PY } \leq 10\end{array}$ & 138 & $\begin{array}{l}\text { Pre-BD } \\
\mathrm{FEV}_{1} \text { : } \\
58 \% \text { pred. }\end{array}$ & $\begin{array}{l}\text { Longitudinal, } 8 \text { weeks } \\
\text { of tiotropium in addition } \\
\text { to convention therapy, } \\
\text { to evaluate predictor factors } \\
\text { of response (improvement } \\
\text { in } \mathrm{FEV}_{1} \geq 15 \% \text { ) }\end{array}$ & $\begin{array}{l}33,3 \% \text { of patients responded } \\
\text { to tiotropium. The presence } \\
\text { of Arg16Gly in ADRB2 } \\
\text { was associated with response } \\
\text { to tiotropium }\end{array}$ & \\
\hline $\begin{array}{l}\text { Peters } \\
2010[5]\end{array}$ & $\begin{array}{l}\text { Asthma, } \\
\text { FEV }_{1}>40 \% \\
\text { of pred., } \\
\text { PY } \leq 10\end{array}$ & 210 & $\begin{array}{l}\text { Pre-BD } \\
\mathrm{FEV}_{1}: \\
71.5 \% \text { pred. }\end{array}$ & $\begin{array}{l}\text { Randomised, placebo- } \\
\text { controlled, crossover; } \\
14 \text { weeks of tiotropium } \\
\text { or salmeterol + ICS } \\
\text { vs double-dose ICS }\end{array}$ & $\begin{array}{l}\text { Increase in morning and evening } \\
\text { PEF, and pre-BD FEV } \\
\text { tiotropium/ICS vs double-dose ICS. } \\
\text { Increase in morning and evening } \\
\text { PEF in LABA/ICS vs double-dose } \\
\text { ICS. Increase in pre-BD FEV }_{1} \\
\text { and post-BD FEV } \text { in tiotropium }_{1} \\
\text { vs salmeterol }\end{array}$ & $\begin{array}{l}\text { Increase in } \\
\text { asthma-control } \\
\text { days and reduction } \\
\text { in daily-symptom } \\
\text { score and ACQ } \\
\text { in tiotropium } \\
\text { and salmeterol } \\
\text { vs double-dose ICS. } \\
\text { No difference between } \\
\text { tiotropium } \\
\text { and salmeterol }\end{array}$ \\
\hline $\begin{array}{l}\text { Kerstjens } \\
2011[6]\end{array}$ & $\begin{array}{l}\text { Severe, } \\
\text { persistent } \\
\text { asthma, } \\
\mathrm{FEV}_{1} \leq 80 \% \\
\text { of pred., } \\
\text { PY } \leq 10\end{array}$ & 107 & $\begin{array}{l}\text { Pre-BD } \\
\mathrm{FEV}_{1} \text { : } \\
58 \% \text { pred. }\end{array}$ & $\begin{array}{l}\text { Randomised, placebo- } \\
\text { controlled, crossover; } \\
8 \text { weeks of ICS+LABA+ } \\
\text { tiotropium } 10 \text { mcg } \\
\text { or ICS+LABA+tiotropium } \\
5 \text { mcg or ICS+LABA } \\
\text { +placebo }\end{array}$ & $\begin{array}{l}\text { Increase in peak of } \mathrm{FEV}_{1} \text { and } \\
\mathrm{FVC} \text {, in trough } \mathrm{FEV}_{1} \text { and } \mathrm{FVC} \\
\text { at the end of the dosing interval, } \\
\text { in } \mathrm{FEV}_{1} \text { and } \mathrm{FVC} \text { area under } \\
\text { curve from } 0 \text { to } 3 \mathrm{~h} \text {, in weekly } \\
\text { mean predose morning PEF, } \\
\text { in both doses of tiotropium } \\
\text { vs placebo }\end{array}$ & $\begin{array}{l}\text { No significant } \\
\text { differences in the } \\
\text { use of rescue } \\
\text { medication, } \\
\text { in the symptom } \\
\text { scores and in } \\
\text { mini-AQLQ } \\
\text { score }\end{array}$ \\
\hline $\begin{array}{l}\text { Bateman } \\
2011 \text { [7] }\end{array}$ & $\begin{array}{l}\text { Asthma, } \\
\text { B16-Arg/ } \\
\text { Arg genotype, } \\
\text { pre-BD } \\
\text { FEV }_{1} \leq 80-90 \% \\
\text { of pred., } \\
\text { PY } \leq 10\end{array}$ & $\begin{array}{l}388 \\
6 \\
6\end{array}$ & $\begin{array}{l}\text { Pre-BD } \\
\mathrm{FEV}_{1}: \\
75 \% \text { pred. }\end{array}$ & $\begin{array}{l}\text { Randomised, placebo- } \\
\text { controlled, parallel-group } \\
\text { study; } 16 \text { weeks of ICS+ } \\
\text { salmeterol or ICS+tiotropium } \\
5 \text { mcg or ICS+placebo after } \\
\text { a run-in period with ICS+ } \\
\text { salmeterol }\end{array}$ & $\begin{array}{l}\text { Decrease in morning PEF and } \\
\text { morning pre-dose } \mathrm{FEV}_{1} \text { in } \\
\text { ICS+placebo vs ICS+salmeterol } \\
\text { and ICS+tiotropium. } \\
\text { No difference between } \\
\text { ICS+salmeterol and } \\
\text { ICS+tiotropium }\end{array}$ & $\begin{array}{l}\text { Significant } \\
\text { difference vs } \\
\text { placebo in the use } \\
\text { of rescue } \\
\text { medication, } \\
\text { symptom score, } \\
\text { asthma-control } \\
\text { days and mini- } \\
\text { AQLQ only } \\
\text { for salmeterol }\end{array}$ \\
\hline $\begin{array}{l}\text { Kerstjens } \\
2012[8]\end{array}$ & $\begin{array}{l}\text { Severe, } \\
\text { persistent } \\
\text { asthma, } \\
\mathrm{FEV}_{1} \leq 80 \% \\
\text { of pred., }\end{array}$ & 912 & $\begin{array}{l}\text { Pre-BD } \\
\text { FEV }_{1}: \\
54.8 \% \text { pred. }\end{array}$ & $\begin{array}{l}\text { Randomised, placebo- } \\
\text { controlled, parallel group; } \\
48 \text { weeks of ICS+LABA+ } \\
\text { tiotropium } 5 \text { mcg or ICS+ } \\
\text { LABA+placebo }\end{array}$ & $\begin{array}{l}\text { At } 24 \text { weeks, greater increase } \\
\text { in the peak } \mathrm{FEV}_{1} \text { and in trough } \\
\mathrm{FEV}_{1} \text { from baseline with } \\
\text { tiotropium than with placebo }\end{array}$ & $\begin{array}{l}\text { Increase in the } \\
\text { time to the first } \\
\text { severe exacerbation } \\
\text { with tiotropium. } \\
\text { Small improvements } \\
\text { in ACQ and AQLQ } \\
\text { with tiotropium }\end{array}$ \\
\hline
\end{tabular}

Abbreviations: RCT: Randomised Clinical Trials; ACQ: Asthma Control Questionnaire; AQLQ: Asthma Quality of Life; ICS: inhaled corticosteroids, LABA: long-acting $\beta 2$-agonists; $\mathrm{FEV}_{1}$ : Forced expired volume in $1 \mathrm{~s}$; FVC: Forced Vital Capacity; Pre-BD: value measured pre-bronchodilator; PEF: Peak Expiratory Flow; Raw: airway Resistance. 
$\mathrm{FEV}_{1}$ of more than $40 \%$ of the predicted value (mean pre-bronchodilator $\mathrm{FEV}_{1}: 71.5 \%$ ) [5]. The addiction of tiotropium to ICS showed a superiority to the doubling dose ICS for the morning PEF (mean difference $25.8 \mathrm{~L} / \mathrm{min}, \mathrm{p}<0.001$ ), that was the primary outcome, and for most secondary outcomes including evening PEF (mean difference 35.3 L/min, $\mathrm{p}<0.001$ ), pre- and post-bronchodilator $\mathrm{FEV}_{1}$ (mean difference $0.10 \mathrm{~L}, \mathrm{p}=0.004$ and $0.04 \mathrm{~L}, \mathrm{p}=0.01$ respectively), proportion of asthma-control days (with a difference of 0.079 , $\mathrm{p}=0.01$ ), daily symptoms score, and Asthma Control Questionnaire (with a difference of -0.18 points, $\mathrm{p}=0.02$ ). Also the addiction of salmeterol to ICS, compared with doubling dose ICS, showed an improvement in these outcomes, except in pre- and post-bronchodilator $\mathrm{FEV}_{1}$ (in particular for the morning PEF, mean difference was $19.4 \mathrm{~L} / \mathrm{min}$, $\mathrm{p}<0.001$ and for the evening PEF, mean difference was $24.7 \mathrm{~L} / \mathrm{min}, \mathrm{p}<0.001)$. There were no significant differences between tiotropium and salmeterol treatments with respect to morning PEF (mean difference in change from baseline for tiotropium vs salmeterol $+6,4 \mathrm{~L} / \mathrm{min}$ ), evening $\mathrm{PEF}$, number of asthma-control days, daily symptoms score and Asthma Control Questionnaire. The tiotropium treatment was superior to the salmeterol treatment with respect to the pre- and postbronchodilator $\mathrm{FEV}_{1}$ measured in the morning (mean difference $0.11 \mathrm{~L}, \mathrm{p}=0.003$ and $0.07 \mathrm{~L}$, $\mathrm{p}<0.001$ respectively).

These results were confirmed in the study by Bateman, performed on a population of asthmatics with similar functional findings and uncontrolled with ICS alone, but with the genetic characteristic of having the B16-Arg/Arg genotype [7]. The background for conducting the study only in this asthmatic population came from the previous observation that the polymorphism in 16 position of $\beta 2$-agonist receptor could be associated to a lower response to the stimulation by $\beta 2$-agonists, an increased risk of adverse effects by use of $\beta 2$-agonists, and this might predispose to a higher response rate to tiotropium. In the study by Bateman, 388 asthmatics, after a 4-week run-in period with $50 \mu \mathrm{g}$ of twice-daily salmeterol, were randomized to 16 weeks of treatment with $5 \mu \mathrm{g}$ Respimat tiotropium once daily, or $50 \mu \mathrm{g}$ salmeterol twice daily, or placebo, always maintaining ICS therapy. The primary endpoint was the change in weekly PEF from the last week of the run-in period to the last week of active treatment. Mean weekly morning pre-dose PEF was maintained during the treatment period with tiotropium and salmeterol, but decreased in patients who switched to placebo (-3.9 L/min for tiotropium, $-3.2 \mathrm{~L} / \mathrm{min}$ for salmeterol and $-24.6 \mathrm{~L} / \mathrm{min}$ for placebo, $\mathrm{p}<0.05)$. Tiotropium was not inferior to salmeterol (estimate difference $-0.78 \mathrm{~L} / \mathrm{min}$ ) and both tiotropium and salmeterol were superior to placebo. Similar results were obtained for mean weekly evening PEF, $\mathrm{FEV}_{1}$ and FVC (for mean weekly pre-dose $\mathrm{FEV}_{1}$ : +0.01 L for tiotropium, $-0.01 \mathrm{~L}$ for salmeterol and $-0.10 \mathrm{~L}$ for placebo). The aim of this study was to demonstrate the similar efficacy of tiotropium and salme- terol in a group of asthmatics considered at increased risk of adverse effects through the use of $\beta 2$-agonists and possibly better responders to anticholinergics (on the basis of study by Park et al). Before the publication of this study, extensive prospective studies have shown the safety of use of ß2-agonists in Arg/Arg asthmatics [18, 19], but the demonstration of a similar efficacy of LABA and tiotropium is still important from a clinical point of view. It is important to note, though, that a similar improvement in pulmonary function was observed in the Bateman study in comparison with the Peters study (mean difference in morning PEF: 20.7 $\mathrm{L} / \mathrm{min}$ vs $25.8 \mathrm{~L} / \mathrm{min}$; mean difference in pre-bronchodilator $\mathrm{FEV}_{1}$ : $0.113 \mathrm{~L}$ vs $0.100 \mathrm{~L}$ ). However, in the Bateman study the results on patient-related aoutcomes were quite disappointing, with no significant improvement in tiotropium vs placebo on daytime asthma symptoms (change from baseline: placebo: 0.015 , n.s.; salmeterol: -0.221 , n.s.; tiotropium: -0.088 , n.s.; significant differences in placebo vs salmeterol but not in placebo vs tiotropium), rescue medication use (change from baseline: placebo: 0.294, n.s.; salmeterol: -0.273, n.s.; tiotropium: -0.074 , n.s.; significant differences in placebo vs salmeterol but not in placebo vs tiotropium) and quality of life (evaluated by Mini-Asthma Quality of Life Questionnaire, change from baseline: placebo: 0.039, n.s.; salmeterol: 0.280 , n.s.; tiotropium: 0.131 , n.s.; significant differences in placebo vs salmeterol but not in placebo vs tiotropium). There was no significant differences between the two active treatments on these outcomes.

Similar results were also obtained in patients with severe asthma when it was added to ICS+LABA. Kerstjens et al performed a randomized, double-blind, crossover study on 107 patients with uncontrolled severe asthma (mean pre-bronchodilator $\mathrm{FEV}_{1}$ of $58 \%$ ) despite treatment with high-dose ICS plus LABA and evaluated the efficacy and safety of the addiction of 2 doses of tiotropium (5 $\mathrm{mcg}$ and $10 \mathrm{mcg}$ daily), compared with placebo, to a treatment regimen of glucocorticoids and LABAs for 8 weeks [6]. The mean peak $\mathrm{FEV}_{1}$ response in the first 3 hours after dosing at the end of the 8-week treatment period (the primary outcome) was significantly superior to placebo with both tiotropium doses $(5 \mathrm{mcg}$ : difference with placebo $139 \mathrm{~mL}, \mathrm{p}<0.001,10 \mathrm{mcg}$ : difference with placebo $170 \mathrm{~mL}, \mathrm{p}<0.001)$. Both doses of tiotropium were significantly superior compared with placebo in all other functional assessments: trough $\mathrm{FEV}_{1}$ (5 mcg: difference from placebo $86 \mathrm{~mL}$, $\mathrm{p}<0.001,10 \mathrm{mcg}$ : difference with placebo $113 \mathrm{~mL}$, $\mathrm{p}<0.001$ ), mean peak FVC in the first 3 hours after dosing, trough FVC and FVC AUC 0-3h, the weekly mean predose morning and evening PEF for weeks 4-8 (for morning PEF, difference with placebo: $7.9 \mathrm{~L} / \mathrm{min}, \mathrm{p}=0.02$ with $5 \mathrm{mcg}$, and 15.3 $\mathrm{L} / \mathrm{min}, \mathrm{p}<0.001$ with $10 \mathrm{mcg})$. Despite these impressive results in lung function, it did not demonstrate any significant effects on clinical parameters. In fact there were no significant differences among the 3 treatments in the rescue medication 
use, the mini-AQLQ score (change over the entire period treatment: placebo: 0.108 , tiotropium 5 mcg: 0.205; tiotropium 10 mcg: 0.206) and in the symptom scores measured with an electronic asthma diary (for asthma symptoms day, change over the entire period treatment: placebo: -0.121 , for tiotropium $5 \mathrm{mcg}$ : -0.140 ; for tiotropium $10 \mathrm{mcg}$ : $-0.152)$.

An important study is that carried out by Magnussen et al [3], and conducted on a subgroup of patients with COPD and a history of asthma diagnosed before $40 \mathrm{yrs}$ of age. In this randomized, placebo-controlled study, 472 patients with diagnosis of asthma and COPD were treated with tiotropium or placebo for 12 weeks in addition to current therapy. Patients were allowed to continue treatments with ICS (inhaled steroid use was an inclusion criteria), LABA, theophylline, leukotriene inhibitors and/or oral corticosteroids. Tiotropium led to a significant improvement not only in the primary endpoint, that was the change in $\mathrm{FEV}_{1}$ area under the curve over from 0 to $6 \mathrm{~h}$ (difference $=186 \pm 24 \mathrm{~mL}, \mathrm{p}<0.001)$ after 12 weeks of treatment, but also in all secondary outcomes: morning pre-dose $\mathrm{FEV}_{1}$, FVC AUC 0-6 h, morning predose FVC, morning and evening PEF and the use of rescue medications (the mean weekly number of daily puffs of salbutamol was reduced by $0.05 \pm 0.12 \mathrm{puffs} /$ day in the placebo group and by $0.50 \pm 0.12 \mathrm{puffs} /$ day in the tiotropium group at week $12, \mathrm{p}<0.05$ ).

\section{Tiotropium in asthma: pivotal studies}

Two replicate randomized, double-blind, cross-over studies were conducted by Kerstjens et al on patients with severe asthma on treatment with high dose ICS plus LABA [8]. These studies included patients with uncontrolled asthma (ACQ score $\geq 1.5$ ) and persistent airflow limitations (defined as a post-bronchodilator $\mathrm{FEV}_{1}$ of $80 \%$ or less of the predicted value, after the inhalation of 4 puffs of $100 \mu \mathrm{g}$ of salbutamol) despite daily therapy with ICS, with at least one exacerbation in the previous year, nonsmokers or ex smokers with a smoking history of less than 10 pack-years. These two studies were conducted on large samples (459 and 453 patients, respectively) and over a long time period (48 weeks) and had, in addiction to two lung-function primary endpoints (the peak $\mathrm{FEV}_{1}$ response in the first 3 hours after dosing and the trough $\mathrm{FEV}_{1}$ response at week 24), also a third important co-primary endpoint: the time to the first severe asthma exacerbation (defined as a deterioration of asthma necessitating initiation or at least a doubling of systemic glucocorticoids for $\geq 3$ days). The patients had a mean baseline $\mathrm{FEV}_{1}$ of $62 \%$ of predicted value. As in previous studies, the addiction to tiotropium again confirmed the improvement of functional parameters (at week 24, the mean difference between tiotropium and placebo groups in the change in peak $\mathrm{FEV}_{1}$ from baseline in the first 3 hours was $86 \pm 34 \mathrm{ml}$ in trial 1 $(\mathrm{p}<0.05)$ and $154 \pm 32 \mathrm{ml}$ in trial $2(\mathrm{p}<0.001)$, and in the change from baseline in the trough $\mathrm{FEV}_{1}$ was $88 \pm 31 \mathrm{ml}$ in trial $1(\mathrm{p}<0.01)$ and $111 \pm 30 \mathrm{ml}$ in trial $2(\mathrm{p}<0.001)$, but especially increased the time to the first severe exacerbation (282 days vs. 226 days, corresponding to a reduction of $21 \%$ in risk, hazard ratio: $0.79, \mathrm{p}=0.03$ ) (figure 1 ). As for the clinical parameters, once again their improvements (number of symptom-free days, use of res-

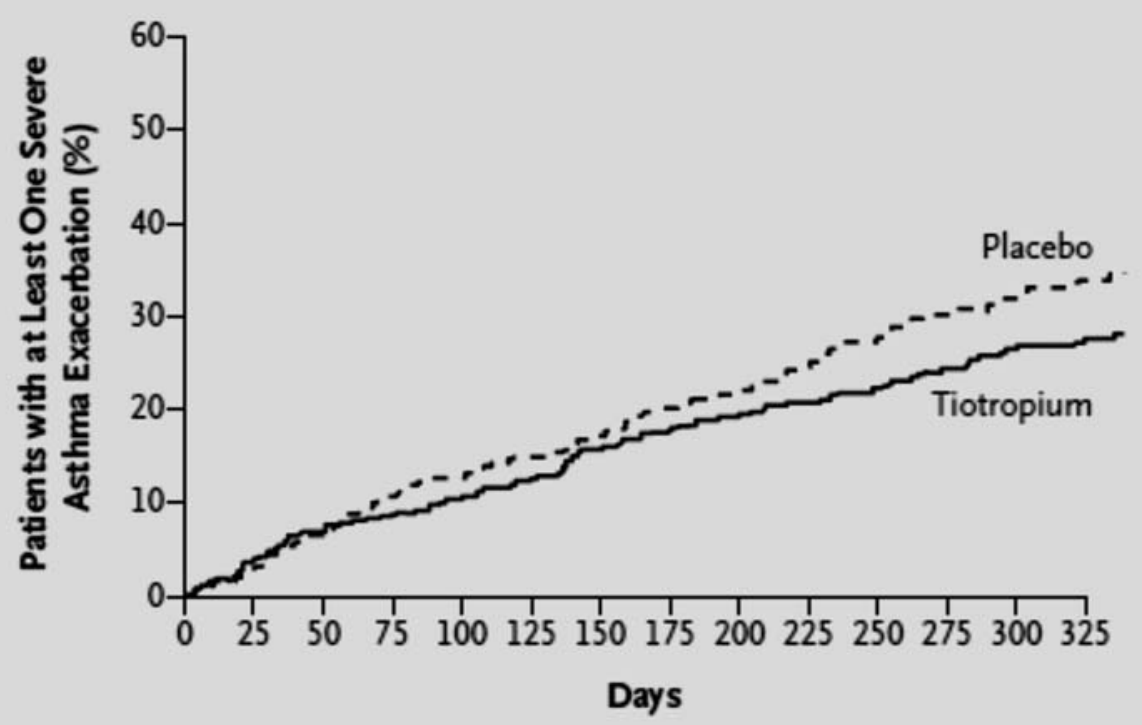

No. at Risk

Placebo

$\begin{array}{llllllllllllll}454 & 435 & 412 & 338 & 379 & 367 & 356 & 339 & 332 & 319 & 303 & 290 & 282 & 272\end{array}$

Tiotropium

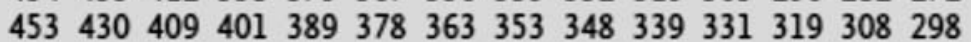

Fig. 1. - Effect of tiotropium on reduction of severe exacerbations in patients with severe asthma. Cumulative number of severe exacerbations in patients with tiotropium therapy in comparison with placebo, with a risk reduction of $21 \%$ (hazard ratio, 0.79 ; $\mathrm{P}=0.03$ ) (with permission, from reference \# 8). 
cue medications, ACQ and AQLQ scores) were small and inconsistent and, for ACQ and AQLQ scores, did not reach the minimal clinically significant difference of 0.5 . The safety profile was extremely good, with no difference in the rate of major and minor adverse events between tiotropium and placebo.

Recent subanalyses of this study have been presented at some major Respiratory International Meetings, showing that the response to tiotropium is consistent throughout a large variety of characteristics from asthmatic subjects (atopic vs non atopic, severe vs non severe airway obstruction, different asthma durations, different age groups, etc.).

\section{Safety of tiotropium in asthma}

Recently, a large debate on the safety of tiotropium, administered by the Respimat inhaler, has been developed, with regard to a potential increased risk of cardiovascular events in COPD patients [21]. Therefore, the safety profile of tiotropium in asthma has been assessed. In the preliminary studies on the relatively low number of patients, no significant excess of adverse events were observed in patients treated with tiotropium in comparison with placebo or other comparators. In the most extensive study, carried out on more than 900 patients [8], half of them treated with tiotropium for one year, adverse events were reported in $73.5 \%$ from the tiotropium group and in $80.3 \%$ from the placebo group. No major events attributed to tiotropium were reported; in particular, cardiac adverse events occurred in less than $2 \%$ of the patients and all were well balanced throughout the study groups. Therefore, the safety of tiotropium in asthma appears to be good.

\section{General considerations}

The various studies of tiotropium in asthma demonstrate that tiotropium is effective in improving lung function. In patients with moderate asthma and not adequately controlled with ICS alone, tiotropium is non-inferior to salmeterol and superior to both placebo and doubling doses of ICS (with possible steroid-sparing effects) in improving the lung function. In patients with severe asthma uncontrolled despite high dose ICS plus LABA, the addiction of tiotropium still provides significant improvements in lung function. Surprisingly, almost all studies show only modest and often insignificant benefits regarding symptoms and quality of life.

The regulatory studies also show a significant reduction in severe exacerbations when tiotropium is added to ICS plus LABA in severe asthmatics. Previously, only the studies by Peters and Magnussen had reported data suggesting a possible role of tiotropium in reducing exacerbation rate (in the study by Peters an asthma exacerbation occurred in 7 patients receiving tiotropium, in 13 receiving double-dose corticosteroids and in 5 receiving salmeterol, and in the study by Magnussen, an exacerbation of COPD and asthma occurred in $11.5 \%$ of the patients receiving placebo and $6.6 \%$ of the patients receiving tiotropium).

One aspect which deserves to be investigated in future studies is the link between tiotropium and airway inflammation. As regards the possible impact on airway inflammation, there are only few observations in the studies carried out by Fardon [2] and Peters [5]. In the first paper there was a little but significant reduction $(2.86 \mathrm{ppb})$ in exhaled nitric oxide (FENO) during treatment with fluticasone propionate/salmeterol/tiotropium bromide compared with fluticasone propionate alone, while in the second study, patients had at baseline a FENO of $18.8 \mathrm{ppb}$ and a normal sputum eosinophilia of $0.40 \times 10^{6}$ cells, and no treatment determined a significant change in these biomarkers. As for the possible different responsivenesses to tiotropium of different inflammatory phenotypes of asthma, Iwamoto et al studied 17 severe persistent asthmatics and observed a positive correlation between sputum neutrophils and $\mathrm{FEV}_{1}$ improvement after 4 weeks of therapy, and an inverse correlation between sputum eosinophils and improvement in $\mathrm{FEV}_{1}$ after 4 weeks of therapy [20], suggesting that tiotropium may be particularly effective in non-eosinophilic asthma.

In summary, the data produced up until now regarding the efficacy and safety of tiotropium in asthma have shown:

a) A significant improvement in lung function, both when tiotropium was added to ICS alone in patients with moderate asthma, and when it was added to ICS+LABA in patients with severe asthma and in patients with concomitant asthma and COPD. The comparison with salmeterol demonstrated similar improvements in morning PEF and similar or greater improvements in pre-dose $\mathrm{FEV}_{1}$.

b) A significant reduction of the risk of asthma exacerbations when added to ICS+LABA in patients with severe asthma and persistent airflow limitation

c) A mild improvement in the control of asthma symptoms and in quality of life, with a reduction in the use of rescue medications in patients of asthma and COPD, controversial results in patient with moderate asthma (improvement in proportion of asthma-control days, daily symptoms score and Asthma Control Questionnaire in the study of Peters, and no change in daytime asthma symptoms, use of rescue medications and quality of life in the study of Bateman), and inconsistent change in asthma control and quality of life scores in patients with severe asthma.

\section{Future perspectives}

Asthma management still requires new drugs and new therapeutic strategies, in order to improve the level of asthma control in the general practice. This may be particularly relevant in severe asthmatics who may be still remain symptomatic despite high doses of ICS and LABA. Therefore, the demonstration of the efficacy of tiotropium along 
with the currently available treatment represent a valid option for the management of more severe asthmatics. Furthermore, the potential for tiotropium to be an alternative to LABA in the addition to low-medium doses of ICS might be relevant, taking into account the warning that some regulatory authorities have issued regarding the risks of using LABA in asthmatic subjects [22]. Although these warnings do not seem appropriate according to the results of the major clinical trials showing the long-term safety of LABAs when added to ICS in asthmatics [23], adding tiotropium (instead of LABA) to ICS may represent a valid alternative.

In more recent years, a program for studying the efficacy of tiotropium in asthma (TinA project) has been developed, and in the near future data on the efficacy of tiotropium in mild and moderate asthmatics are on hold. In particular, studies have been completed on the addition of tiotropium to low dose ICS vs ICS alone in mild asthmatics, either with the addition of tiotropium or salmeterol to medium dose ICS vs ICS alone in moderate asthmatics. The results will be available in the near future.

If these results prove to be positive, it will remain to be seen which patients may be appropriate for treatment with either LABA or tiotropium, leading to a more customized treatment according to some specific phenotypes.

Therefore, tiotropium is set to become a further yet important resource for the management of asthmatic patients and improvement in the control of the disease.

\section{References}

1. Lewis MJ, Short AL, Lewis KE. Autonomic nervous system control of the cardiovascular and respiratory systems in asthma. Respir Med 2006; 100: 1688-1705.

2. Fardon T, Haggart K, Lee DKC, Lipworth BJ. A proof of concept study to evaluate stepping down the dose of fluticasone in combination with salmeterol and tiotropium in severe persistent asthma. Respir Med 2007; 101: 1218-1228.

3. Magnussen H, Bugnas B, van Noord J, Schmidt P, Gerken F, Kesten S. Improvements with tiotropium in COPD patients with concomitant asthma. Respir Med 2008; 102: 50-56.

4. Park HW, Yang MS, Park CS, et al. Additive role of tiotropium in severe asthmatics and Arg16Gly in ADRB2 as a potential marker to predict response. Allergy 2009; 64: 778-783.

5. Peters SP, Kunselman SJ, Icitovic N, et al. Tiotropium bromide step-up therapy for adults with uncontrolled asthma. N Engl J Med 2010; 363: 1715-1726.

6. Kerstjens HA, Disse B, Schröder-Babo W, et al. Tiotropium improves lung function in patients with severe uncontrolled asthma: a randomized controlled trial. J Allergy Clin Immunol 2011; 128: 308-314.

7. Bateman ED, Kornmann O, Schmidt P, Pivovarova A, Engel M, Fabbri LM. Tiotropium is noninferior to salmeterol in maintaining improved lung function in B16Arg/Arg patients with asthma. $J$ Allergy Clin Immunol 2011; 128: 315-322.
8. Kerstjens HA, Engel M, Dahl R, et al. Tiotropium in asthma poorly controlled with standard combination therapy. N Engl J Med 2012; 367: 1198-1207.

9. Fabbri LM, Hendrck DJ, Diem JE. Effect of atropine on the bronchial response of asthmatic subjects to the inhalation of ultrasonically nebulized distilled water. $J$ Allergy Clin Immunol 1983; 71: 468-472.

10. Sheppard D, Epstein J, Holtzman MJ, Nadel JA, Boushey HA. Dose-dependent inhibition of cold air-induced bronchoconstriction by atropine. J Appl Physiol 1982; 53: 169-174.

11. Fish JE, Rosenthal RR, Summer WR, Menkes H, Norman SP, Permut S. The effect of atropine on acute antigen-mediater airway constriction in subjects with allergic asthma. Am Rev Respir Dis 1977; 115: 371-379.

12. Thiessen B, Pedersen OF. Maximal expiratory flows and forced vital capacity in normal, asthmatic and bronchitic subjects after salbutamol and ipratropium bromide. Respiration 1982; 43: 304-316.

13. Higgins BG, Powell RM, Cooper S, Tattersfield AE. Effect of salbutamol and ipratropium bromide on airway caliber and bronchial reactivity in asthma and chronic bronchitis. Eur Respir J 1991; 4: 415-420.

14. Jindal SK, Kaur SJ. Relative bronchodilatory responsiveness attributable to sympathetic and parasympathetic activity in bronchial asthma. Respiration 1989; 56: $16-21$.

15. Chhabra SK, Pandey KK. Comparison of acute bronchodilator effects of inhaled ipratropium bromide and salbutamol in bronchial asthma. J Asthma 2002; 39: 375-381.

16. Ahmed Z, Singh SK. Relative and additional bronchodilator response of salbutamol and ipratropium in smoker and nonsmoker asthmatics. J Asthma 2010; 47: 340-343.

17. Cox ID, Hughes DT, McDonnell KA. Ipratropium bromide in patients with nocturnal asthma. Postgrad Med $J$ 1984; 60: 526-528.

18. Bleecker ER, Postma DS, Lawrance RM, Meyers DA, Ambrose HJ, Goldman M. Effect of ADRB2 polymorphisms on response to longacting beta2-agonist therapy: a pharmacogenetic analysis of two randomised studies. Lancet 2007; 370: 2118-2125.

19. Bleecker ER, Nelson HS, Kraft M, et al. Beta2-receptor polymorphisms in patients receiving salmeterol with or without fluticasone propionate. Am J Respir Crit Care Med 2010; 181: 676-687.

20. Iwamoto H, Yokoyama A, Shiota N, et al. Tiotropium bromide is effective for severe asthma with noneosinophilic phenotype. Eur Resp J 2008; 31: 13791380.

21. Singh S, Loke YK, Enright PL, Furberg CD. Mortality associated with tiotropium mist inhaler in patients with chronic obstructive pulmonary disease: systematic review and meta-analysis of randomised controlled trials. BMJ 2011; 342: d3215.

22. Levenson M. Long-acting beta-agonists and adverse asthma events meta-analysis: statistical briefing package for joint meeting of the Pulmonary - Allergy Drugs Advisory Committee, Drug Safety and Risk Management Advisory Committee, and Pediatric Advisory Committee on December 10-11, 2008 (Accessed March 27, 2009, at http:// www.fda.gov/ohrms/dockets/ac/08/ briefing/2008-4398b1-01-FDA.pdf).

23. Chowdhury BA, Dal Pan G. The FDA and safe use of long-acting beta-agonists in the treatment of asthma. $N$ Engl J Med 2010; 362: 1169-1171. 